\title{
DETERMINAN PEMBIAYAAN USAHA MIKRO KECIL DAN MENENGAH PADA BANK PEMBIAYAAN RAKYAT SYARIAH DI INDONESIA
}

\author{
Rina Destiana \\ Universitas Swadaya Gunung Jati \\ rinadestiana@unswagati.ac.id \\ Siti Jubaedah \\ Universitas Swadaya Gunung Jati \\ edahcrb@gmail.com
}

\begin{abstract}
ABSTRAK
Tujuan penelitian ini adalah menguji dan menganalisis pengaruh ukuran bank, efisiensi, likuiditas dan BI rate terhadap pembiayaan UMKM pada Bank Pembiayaan Rakyat Syariah (BPRS) di Indonesia. Data penelitian berupa data sekunder yang diperoleh dari situs resmi Bank Indonesia. Data tersebut dianalisis menggunakan analisis regresi linear berganda. Sebelum data dianalisis lebih lanjut, dilakukan beberapa pengujian asumsi klasik terlebih dahulu yang meliputi uji normalitas, uji multikolinearitas, uji heteroskedastisitas dan uji autokorelasi. Berdasarkan pengujian hipotesis menggunakan uji $t$ maka disimpulkan bahwa ukuran bank berpengaruh positif terhadap pembiayaan UMKM, efisiensi tidak berpengaruh terhadap pembiayaan UMKM, likuiditas berpengaruh positif terhadap pembiayaan UMKM dan BI rate tidak berpengaruh terhadap pembiayaan UMKM.
\end{abstract}

Kata kunci : Aset, BI rate, efisiensi, likuiditas, pembiayaan, UMKM

\section{PENDAHULUAN}

Sektor Usaha Mikro Kecil dan Menengah (UMKM) memiliki peranan penting dalam mendorong percepatan pembangunan ekonomi di Indonesia. Dengan adanya sektor UMKM, angka pengangguran di Indonesia menjadi berkurang. Sektor UMKM telah terbukti menjadi pilar perekonomian yang tangguh. Terbukti saat terjadi krisis ekonomi 1998 di Indonesia, hanya sektor UMKM yang bertahan dari collapse-nya perekonomian. UMKM memiliki kekuatan yang tidak dimiliki oleh perusahaan-perusahaan skala besar. Pada masa sulit dewasa ini, UMKM cukup fleksibel menyikapi kenaikan harga bahan bakar dan kenaikan harga faktor-faktor produksi lainnya. Kontribusi UMKM dalam peningkatan Produk Domestik
Bruto dan devisa negara juga tak diragukan lagi. Mengingat peranan dan kontribusi UMKM bagi perekonomian bangsa maka UMKM dijadikan agenda utama pembangunan ekonomi Indonesia. Saat ini kebijakan pemerintah telah menunjukkan keberpihakan kepada UMKM.

Untuk penguatan sektor UMKM di Indonesia, sudah tentu UMKM membutuhkan dukungan salah satunya dari sektor perbankan. Perbankan menjalankan fungsinya sebagai financial intermediary dimana salah satu fungsinya adalah menyalurkan kredit atau pembiayaan kepada masyarakat. Penyaluran pembiayaan kepada UMKM dirasa sangat penting mengingat kebutuhan untuk modal kerja diperlukan oleh UMKM. Namun dalam kenyataannya 
untuk mengakses pembiayaan bank bagi UMKM tidaklah mudah. Sebagaimana yang dikemukakan Hubeis (2009) dalam Akbar (2013) bahwa UMKM masih dihadapkan dengan beberapa masalah, dimana salah satunya menyangkut akses terhadap sumber-sumber pemdanaan dari institusi-institusi keuangan formal, khususnya dari perbankan.

Secara teknis, kesulitan perbankan untuk dapat menyalurkan pembiayaan UMKM adalah karena tidak cukupnya agunan yang dimiliki oleh UMKM tersebut. Kesulitan tersebut tidak hanya dialami oleh bank konvensional tetapi juga bank syariah, termasuk Bank Pembiayaan Rakyat Syariah (BPRS). Lebih lanjut, peraturan Bank Indonesia yang mengharuskan bank mengenal dengan baik para nasabahnya (know your customer regulation), kekhawatiran akan munculnya pembiayaan macet dan risiko bisnis lainnya, termasuk risiko reputasi profesionalisme para bankir, memang menjadi faktor jika perbankan masih belum optimal dalam menggarap pangsa UMKM ini. Di sisi UMKM sendiri, perbankan dan lembaga pembiayaan lainnya masih dianggap sangat sulit diakses. Untuk dapat memperoleh pembiayaan, sebagian pelaku UMKM berpendapat bahwa perbankan masih memiliki syarat dan prosedur yang cukup rumit. Meskipun di lain pihak fasilitas pembiayaan telah banyak dikucurkan oleh perbankan, misalnya kemudahan mengakses pembiayaan tanpa agunan, namun syarat adanya pendapatan tetap melalui penyerahan fotokopi slip penghasilan, belum sepenuhnya dimiliki para pengusaha UMKM ini. Akibatnya, perbankan sekarang ini lebih banyak memprioritaskan mereka yang berpenghasilan tetap dengan penyaluran pembiayaan konsumtifnya. Sementara itu para pengusaha UMKM dengan segala sifat tangguh yang melekat padanya, hanya dapat berharap adanya kucuran pembiayaan bagi pengembangan usahanya.

BPRS merupakan tipe bank syariah yang secara khusus diarahkan untuk membiayai UMKM. Namun demikian, terdapat batasan-batasan dan fokus usaha BPRS, yaitu BPRS tidak diperkenankan menghimpun dana pihak ketiga (DPK) dalam bentuk giro, karena BPRS tidak menjalankan fungsi lalu lintas pembayaran dalam sistem pembayaran nasional, persyaratan modal BPRS relatif lebih kecil dibandingkan persyaratan modal bank umum syariah (BUS) dan unit usaha syariah (UUS) agar keberadaan BPRS dapat lebih fokus melayani segmen UMKM yang tersebar di seluruh wilayah Indonesia dan belum sepenuhnya terjangkau oleh jaringan kantor BUS dan UUS (Mulyanto, 2011).

Melihat pentingnya pembiayaan bagi pengembangan dan penguatan sektor UMKM di Indonesia dan peranan BPRS terhadap pengembangan sektor UMKM maka perlu dikaji faktor-faktor yang berpengaruh terhadap penyaluran pembiayaan UMKM pada BPRS di Indonesia. Dengan mengkaji dan menganalisis faktor-faktor yang menentukan penyaluran pembiayaan UMKM pada BPRS di Indonesia diharapkan dapat dicari solusi atas berbagai permasalahan menyangkut keterbatasan BPRS dalam penyaluran pembiayaan kepada sektor UMKM di Indonesia.

Faktor-faktor yang diprediksi berpengaruh terhadap penyaluran pembiayaan UMKM diantaranya ukuran bank, efisiensi, likuiditas dan BI rate. Ukuran bank menunjukkan kemampuan bank untuk membiayai investasi yang menguntungkan serta prospek bank ke depan. Salah satu indikator ukuran bank adalah total aset. Aset adalah harta produktif yang dikelola dalam perusahaan tersebut dan aset ini diperoleh dari sumber utang atau modal (Harahap, 2008). Akbar 
(2013) dan Ferdinandus (2013) dalam penelitiannya menemukan bahwa ukuran bank berpengaruh terhadap penyaluran kredit UMKM.

Faktor berikutnya yang diprediksi berpengaruh terhadap pembiayaan UMKM yang disalurkan oleh bank syariah adalah efisiensi. Efisiensi bank menggambarkan apakah manajemen bank telah menggunakan semua faktor produksinya dengan efektif dan efisien. Nuryakin dan Warjiyo (2006) dalam Satria dan Subegti (2010) menemukan bahwa efisiensi bank berpengaruh terhadap penyaluran kredit bank umum di Indonesia.

Faktor likuiditas juga terbukti berpengaruh terhadap pembiayaan UMKM. Likuiditas adalah kemampuan perusahaan untuk memenuhi kewajiban jangka pendek atau kemampuan untuk melanjutkan kegiatan operasional pada saat perusahaan harus melunasi kewajibannya sehingga akan mengurangi dana operasionalnya. Pengaturan likuiditas ditujukan agar bank setiap saat dapat memenuhi kewajiban-kewajiban yang sifatnya harus segera dipenuhi. Barus dan Lu (2013) dalam penelitiannya membuktikan bahwa LDR sebagai indikator likuiditas berpengaruh signifikan terhadap penyaluran kredit UMKM pada bank umum di Indonesia.

Jika ukuran bank, efisiensi dan likuiditas merupakan faktor internal bank, maka faktor eksternal yang diprediksi berpengaruh terhadap pembiayaan UMKM adalah $\mathrm{BI}$ rate. $\mathrm{BI}$ rate merupakan suku bunga kebijakan yang menggambarkan langkah kebijakan moneter yang diterapkan oleh BI yang diumumkan kepada publik. Meningkatnya $\mathrm{BI}$ rate menyebabkan bank meningkatkan penawaran kreditnya karena bank akan memperoleh pendapatan dari bunga kredit yang lebih besar. Demikian sebaliknya, menurunnya $\mathrm{BI}$ rate menyebabkan turunnya kredit yang diberikan karena bank akan memperoleh bunga kredit lebih kecil. Putra dan Rustariyuni (2015) dalam penelitiannya membuktikan bahwa BI rate mempunyai pengaruh secara signifikan terhadap penyaluran kredit modal kerja pada BPR di Provinsi Bali. Pradana (2013) dan Sari (2013) dalam penelitiannya menemukan bahwa $\mathrm{BI}$ rate berpengaruh signifikan terhadap kredit yang disalurkan.

Berdasarkan uraian tersebut maka peneliti tertarik untuk meneliti faktorfaktor yang mempengaruhi penyaluran pembiayaan UMKM pada BPRS di Indonesia.

Rumusan masalah penelitian ini adalah bagaimana pengaruh ukuran bank, efisiensi, likuiditas dan BI rate terhadap pembiayaan UMKM pada BPRS di Indonesia.

\section{KERANGKA TEORITIS DAN HIPOTESIS}

Ukuran BPRS yang diukur dengan total aset berpengaruh positif terhadap pembiayaan UMKM. Semakin besar ukuran BPRS yang tercermin dari total asetnya maka semakin besar pula pembiayaan yang disalurkan kepada UMKM. Hal ini sejalan dengan hasil penelitian Akbar (2013) dan Ferdinandus (2013) yang membuktikan bahwa ukuran bank berpengaruh positif terhadap penyaluran kredit UMKM.

Semakin kecil rasio BOPO menunjukkan bahwa BPRS semakin efisien. Semakin efisien BPRS berarti semakin besar BPRS menyalurkan pembiayaan kepada sektor UMKM. Hal ini sejalan dengan hasil penelitian Nuryakin dan Warjiyo (2006) dalam Satria dan Subegti (2010) yang menemukan bahwa efisiensi bank berpengaruh negatif terhadap penyaluran kredit bank umum di Indonesia.

Semakin tinggi rasio FDR, menandakan bahwa sebagian besar dana yang berhasil dihimpun oleh BPRS 
tertanam pada pinjaman termasuk pinjaman ke sektor UMKM, hal ini akan menyebabkan BPRS menjadi semakin tidak likuid karena dana pihak ketiganya tertanam pada pembiayaan. Apabila BPRS semakin tidak likuid, maka BPRS akan mengurangi pengucuran pembiayaan kepada masyarakat termasuk pembiayaan ke sektor UMKM. Hal ini sejalan dengan penelitian Barus dan Lu (2013) yang berhasil membuktikan bahwa LDR sebagai indikator likuiditas berpengaruh negatif terhadap penyaluran kredit UMKM pada bank umum di Indonesia.

Meningkatnya $\mathrm{BI}$ rate menyebabkan BPRS meningkatkan penawaran pembiayaannya termasuk kepada sektor UMKM karena BPRS akan memperoleh profit sharing yang lebih besar. Demikian sebaliknya, menurunnya $\mathrm{BI}$ rate menyebabkan turunnya pembiayaan UMKM yang diberikan karena BPRS akan memperoleh profit sharing lebih kecil. Hal ini sejalan dengan penelitian Putra dan Rustariyuni (2015) yang membuktikan bahwa $\mathrm{BI}$ rate berpengaruh positif terhadap kredit modal kerja yang disalurkan BPR di Provinsi Bali. Demikian pula penelitian Pradana (2013) dan Sari (2013) yang juga membuktikan bahwa BI rate berpengaruh positif terhadap kredit yang disalurkan.

Berdasarkan uraian yang sudah dikemukakan maka kerangka pemikiran penelitian digambarkan sebagai berikut:

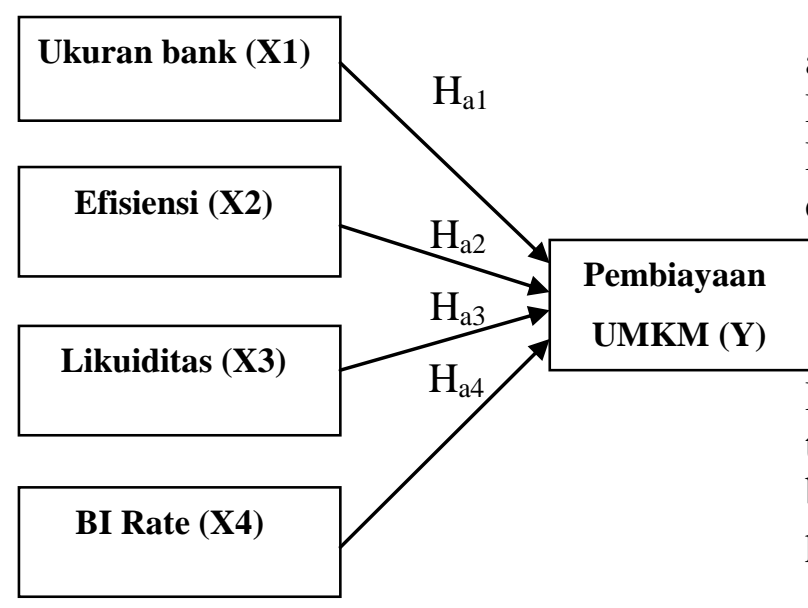

\section{Gambar 1. Kerangka Pemikiran}

Berdasarkan kerangka pemikiran yang bersumber dari telaah teori dan hasil penelitian sebelumnya, maka hipotesis yang diajukan dalam penelitian ini adalah sebagai berikut:

$\mathrm{H}_{\mathrm{a} 1}$ : Ukuran bank berpengaruh positif terhadap pembiayaan UMKM

$\mathrm{H}_{\mathrm{a} 2}$ : Efisiensi berpengaruh negatif terhadap pembiayaan UMKM

$\mathrm{H}_{\mathrm{a} 3}$ : Likuiditas berpengaruh negatif terhadap pembiayaan UMKM

$\mathrm{H}_{\mathrm{a} 4}$ : $\mathrm{BI}$ rate berpengaruh positif terhadap pembiayaan UMKM

\section{METODE PENELITIAN}

Variabel dependen dalam penelitian ini adalah pembiayaan UMKM. Sedangkan variabel independennya adalah ukuran bank, efisiensi, likuiditas dan BI rate. Variabel pembiayaan UMKM diukur dengan jumlah pembiayaan yang disalurkan oleh BPRS kepada UMKM pada periode pengamatan. Variabel ukuran bank diukur dengan total aset BPRS pada periode pengamatan. Variabel efisiensi diukur dengan rasio BOPO BPRS pada periode pengamatan, variabel likuiditas diukur dengan rasio FDR BPRS pada periode pengamatan dan variabel BI rate diukur dengan suku bunga yang ditetapkan oleh Bank Indonesia pada periode pengamatan.

Populasi dalam penelitian ini adalah seluruh BPRS yang ada di Indonesia yang secara statistik terdaftar di Bank Indonesia pada tahun 2013 sampai dengan tahun 2015. Sampel dalam penelitian ini adalah data rata-rata atau data gabungan dari seluruh BPRS di Indonesia yang bersumber dari Laporan Bulanan BPRS selama tiga tahun berturutturut. Mengingat datanya adalah data bulanan maka diperoleh sebanyak 36 pengamatan. 
Data yang digunakan dalam penelitian ini adalah data sekunder yang berasal dari Bank Indonesia, yang bersumber dari Laporan Bulanan BPRS. Data sekunder ini dipublikasikan oleh Bank Indonesia melalui situs resmi www.bi.go.id berupa Statistik Perbankan Syariah. Adapun data untuk variabel BI rate diperoleh juga dari situs resmi Bank Indonesia. Studi dokumentasi digunakan dalam penelitian ini. Studi dokumentasi dilakukan dengan cara mengumpulkan data penelitian yang diperlukan dari Statistik Perbankan Syariah melalui situs www.bi.go.id. Analisis regresi berganda digunakan untuk menguji pengaruh variabel ukuran bank, efisiensi, likuiditas dan BI rate terhadap pembiayaan UMKM
BPRS di Indonesia selama periode pengamatan yaitu tahun 2013 hingga 2015 .

Analisis data dibantu dengan menggunakan program SPSS Statistics 18. Sebelum pengujian hipotesis maka untuk menentukan ketepatan model regresi perlu dilakukan pengujian asumsi klasik yang meliputi uji normalitas, uji multikolinearitas, uji heteroskedastisitas dan uji autokorelasi.

\section{HASIL DAN PEMBAHASAN}

Berikut disajikan tabel hasil pengujian normalitas menggunakan uji Kolmogorov-Smirnov.

Tabel 1. Hasil Uji Kolmogorov-Smirnov

\begin{tabular}{|ll|r|}
\hline & & Standardized Residual \\
\hline Normal Parameters & & 36 \\
& Mean & .0000000 \\
Most Extreme Differences & Std. Deviation & .94112395 \\
& Absolute & .219 \\
& Positive & .198 \\
Kolmogorov-Smirnov Z & Negative & -.219 \\
Asymp. Sig. (2-tailed) & & 1.316 \\
\hline
\end{tabular}

a. Test distribution is Normal.

b. Calculated from data.

Sumber: Data sekunder diolah (2016)

Berdasarkan tabel 1 dapat dilihat bahwa data terdistribusi normal karena nilai Asymp. Sig. Standardized residualnya 0,063 . Nilai ini lebih besar dari 0,05 sehingga disimpulkan bahwa data observasi memenuhi asumsi normalitas.

\section{Hasil Uji Multikolinearitas}

Berikut disajikan tabel hasil pengujian multikolinearitas dengan melihat nilai tolerance dan VIF.

Tabel 2. Hasil Uji Multikolinearitas

\begin{tabular}{|c|c|c|c|c|c|c|c|c|}
\hline \multirow{2}{*}{\multicolumn{2}{|c|}{ Model }} & \multicolumn{2}{|c|}{ Unstandardized Coefficients } & \multirow{2}{*}{$\begin{array}{c}\begin{array}{r}\text { Standardized } \\
\text { Coefficients }\end{array} \\
\text { Beta }\end{array}$} & \multirow[b]{2}{*}{$t$} & \multirow[b]{2}{*}{ Sig. } & \multicolumn{2}{|c|}{$\begin{array}{c}\text { Collinearity } \\
\text { Statistics }\end{array}$} \\
\hline & & B & Std. Error & & & & Tolerance & VIF \\
\hline \multirow[t]{5}{*}{1} & (Constant) & -1695367.288 & 427936.685 & & -3.962 & .000 & & \\
\hline & Total_Aset & .404 & .029 & .856 & 13.716 & .000 & .284 & 3.524 \\
\hline & BOPO & -768.567 & 6046.167 & -.009 & -.127 & .900 & .234 & 4.274 \\
\hline & FDR & 13953.549 & 3047.565 & .167 & 4.579 & .000 & .835 & 1.198 \\
\hline & BI_Rate & 47083.399 & 32754.090 & .083 & 1.437 & .161 & .333 & 3.002 \\
\hline
\end{tabular}


Tabel 2. Hasil Uji Multikolinearitas

\begin{tabular}{|c|c|c|c|c|c|c|c|c|}
\hline \multirow{2}{*}{\multicolumn{2}{|c|}{ Model }} & \multicolumn{2}{|c|}{ Unstandardized Coefficients } & \multirow{2}{*}{$\begin{array}{c}\begin{array}{c}\text { Standardized } \\
\text { Coefficients }\end{array} \\
\text { Beta }\end{array}$} & \multirow[b]{2}{*}{$\mathrm{t}$} & \multirow[b]{2}{*}{ Sig. } & \multicolumn{2}{|c|}{$\begin{array}{c}\text { Collinearity } \\
\text { Statistics }\end{array}$} \\
\hline & & $\mathrm{B}$ & Std. Error & & & & Tolerance & VIF \\
\hline \multirow[t]{5}{*}{1} & (Constant) & -1695367.288 & 427936.685 & & -3.962 & .000 & & \\
\hline & Total_Aset & .404 & .029 & .856 & 13.716 & .000 & .284 & 3.524 \\
\hline & BOPO & -768.567 & 6046.167 & -.009 & -.127 & .900 & .234 & 4.274 \\
\hline & FDR & 13953.549 & 3047.565 & .167 & 4.579 & .000 & .835 & 1.198 \\
\hline & BI_Rate & 47083.399 & 32754.090 & .083 & 1.437 & .161 & .333 & 3.002 \\
\hline
\end{tabular}

a. Dependent Variable: Pembiayaan_UMKM

Sumber: Data sekunder diolah (2016)

Berdasarkan tabel 2 dapat dilihat bahwa tidak ada satupun variabel independen yang memiliki nilai tolerance kurang dari 0,10 dan nilai VIF lebih dari 10. Semua variabel independen memiliki nilai tolerance lebih dari 0,10 dan nilai VIF kurang dari 10 sehingga dapat disimpulkan bahwa tidak terjadi gejala multikolinearitas antar variabel independen. Dengan demikian data observasi memenuhi asumsi multikolinearitas.

\section{Hasil Uji Heteroskedastisitas}

Berikut disajikan tabel hasil pengujian heteroskedastisitas

Tabel 3. Hasil Uji Glejser

\begin{tabular}{|c|c|c|c|c|c|c|}
\hline & \multirow[t]{2}{*}{ Model } & \multicolumn{2}{|c|}{ Unstandardized Coefficients } & \multirow{2}{*}{$\begin{array}{c}\begin{array}{c}\text { Standardized } \\
\text { Coefficients }\end{array} \\
\text { Beta }\end{array}$} & \multirow[b]{2}{*}{$\mathrm{t}$} & \multirow[b]{2}{*}{ Sig. } \\
\hline & & B & Std. Error & & & \\
\hline \multirow[t]{5}{*}{1} & (Constant) & -726551.810 & 324656.674 & & -2.238 & .033 \\
\hline & Total_Aset & .010 & .022 & 133 & 441 & .662 \\
\hline & BOPO & 4029.913 & 4586.960 & .291 & .879 & .386 \\
\hline & FDR & 4443.750 & 2312.053 & .337 & 1.922 & .064 \\
\hline & BI_Rate & -28597.955 & 24849.083 & -.320 & -1.151 & 259 \\
\hline
\end{tabular}

a. Dependent Variable: ABRES

Sumber: Data sekunder diolah (2016)

Berdasarkan tabel 3 dapat dilihat bahwa nilai signifikansi masing-masing variabel independen lebih dari 0,05 sehingga dapat disimpulkan bahwa tidak terjadi gejala heteroskedastisitas pada data observasi.

\section{Hasil Uji Autokorelasi}

Berikut disajikan tabel hasil pengujian autokorelasi menggunakan uji Durbin Watson.

Tabel 4. Hasil Uji Durbin Watson

\begin{tabular}{|c|r|r|r|r|r|}
\hline Model & R & R Square & justed R Square & $\begin{array}{l}\text { Std. Error of the } \\
\text { Estimate }\end{array}$ & \multicolumn{1}{l|}{ Durbin-Watson } \\
\hline 1 & .983 & .966 & .961 & 74668.284 & 1.967 \\
\hline
\end{tabular}

a. Predictors: (Constant), BI_Rate, FDR, Total_Aset, BOPO 


\begin{tabular}{|c|r|r|r|r|r|}
\hline Model & R & R Square & justed R Square & $\begin{array}{l}\text { Std. Error of the } \\
\text { Estimate }\end{array}$ & \multicolumn{1}{c|}{ Durbin-Watson } \\
\hline 1 & .983 & .966 & .961 & 74668.284 & 1.967 \\
\hline
\end{tabular}

a. Predictors: (Constant), BI_Rate, FDR, Total_Aset, BOPO

b. Dependent Variable: Pembiayaan_UMKM

Sumber: Data sekunder diolah (2016)

Berdasarkan tabel 4 dapat dilihat bahwa nilai Durbin Watson adalah 1,967. Nilai ini akan dibandingkan dengan nilai pada Tabel Durbin Watson dengan signifikansi $0,05, \mathrm{~N}$ (jumlah observasi) $=$ 36 dan $\mathrm{k}$ (variabel independen $)=4$.

Nilai pada Tabel Durbin Watson dengan signifikansi $0,05, \mathrm{~N}$ (jumlah observasi) $=36$ dan $\mathrm{k}$ (variabel independen) $=4$ menunjukkan bahwa batas bawah atau $\mathrm{dl}=1,236 \mathrm{dan}$ batas atas atau $d u=1,724$. Nilai DW $(1,967)$ lebih besar dari du $(1,724)$ dan lebih kecil dari (4-du) (2,276). Dalam hal ini nilai DW terletak diantara du dan (4-du) atau du < DW < (4-du). Dengan demikian disimpulkan bahwa data yang diamati terbebas dari gejala autokorelasi.

\section{Analisis Regresi Linear Berganda dan Hasil Uji Hipotesis}

Berikut disajikan tabel analisis regresi linear berganda dan hasil uji hipotesis menggunakan uji $t$ yang dijadikan dasar dalam menyusun model regresi dan pengambilan keputusan diterima atau ditolaknya hipotesis penelitian.

Tabel 5. Analisis Regresi Linear Berganda dan Hasil Uji Hipotesis

\begin{tabular}{|c|c|c|c|c|c|c|}
\hline & \multirow[t]{2}{*}{ Model } & \multicolumn{2}{|c|}{ Unstandardized Coefficients } & \multirow{2}{*}{$\begin{array}{c}\begin{array}{c}\text { Standardized } \\
\text { Coefficients }\end{array} \\
\text { Beta }\end{array}$} & \multirow[b]{2}{*}{$\mathrm{t}$} & \multirow[b]{2}{*}{ Sig. } \\
\hline & & $\mathrm{B}$ & Std. Error & & & \\
\hline \multirow[t]{5}{*}{1} & (Constant) & -1695367.288 & 427936.685 & & -3.962 & .000 \\
\hline & Total_Aset & .404 & .029 & .856 & 13.716 & .000 \\
\hline & BOPO & -768.567 & 6046.167 & -.009 & -.127 & .900 \\
\hline & FDR & 13953.549 & 3047.565 & .167 & 4.579 & .000 \\
\hline & BI_Rate & 47083.399 & 32754.090 & .083 & 1.437 & .161 \\
\hline
\end{tabular}

a. Dependent Variable: Pembiayaan_UMKM

Sumber: Data sekunder diolah (2016)

Berdasarkan tabel 5, model regresi linear berganda dalam penelitian ini adalah:

\section{Pembiayaan UMKM $=-\mathbf{1 6 9 5 3 6 7 , 2 8 8}+$ 0,404 TA - 768,567 BOPO + 13953,549 FDR + 47083,399 BI + e}

Berdasarkan tabel 5 juga, hasil penelitian diuraikan sebaga berikut:

1. Koefisien regresi variabel ukuran bank sebesar 0,404, nilai $t_{\text {hitung }}$ sebesar
13,716 dan signifikansinya 0 . Jika dibandingkan dengan nilai $\mathrm{t}_{\text {tabel }}$ pada Tabel Nilai $t$ (one-tailed) dimana signifikansinya 0,05 dan $\mathrm{df}=31$ maka diperoleh nilai $t_{\text {tabel }}$ sebesar 1,70 . Karena koefisien regresi (b) $>0$, nilai $t_{\text {hitung }}>t_{\text {tabel }}$ dan signifikansinya sebesar 0 maka hipotesis bahwa ukuran bank berpengaruh positif terhadap pembiayaan UMKM diterima. 
2. Koefisien regresi variabel efisiensi sebesar -768.567 , nilai $t_{\text {hitung }}$ sebesar 0,127 dan signifikansinya 0,9 . Jika dibandingkan dengan nilai $\mathrm{t}_{\text {tabel }}$ pada Tabel Nilai $t$ (one-tailed) dimana signifikansinya 0,05 dan $\mathrm{df}=31$ maka diperoleh nilai $t_{\text {tabel }}$ sebesar 1,70. Karena koefisien regresi (b) $<0$, nilai $t_{\text {hitung }} \geq-t_{\text {tabel }}$ dan signifikansinya sebesar 0,9 maka hipotesis bahwa efisiensi bank berpengaruh negatif terhadap pembiayaan UMKM ditolak.

3. Koefisien regresi variabel likuiditas sebesar 13953,549, nilai thitung sebesar 4,579 dan signifikansinya 0 . Jika dibandingkan dengan nilai $t_{\text {tabel }}$ pada Tabel Nilai $t$ (one-tailed) dimana signifikansinya 0,05 dan $\mathrm{df}=31$ maka diperoleh nilai $t_{\text {tabel }}$ sebesar 1,70 . Karena koefisien regresi (b) $>0$, nilai $t_{\text {hitung }}>t_{\text {tabel }}$ dan signifikansinya sebesar 0 maka hipotesis bahwa likuiditas berpengaruh negatif terhadap pembiayaan UMKM ditolak. Hasil penelitian malah membuktikan bahwa likuiditas yang diukur dengan FDR berpengaruh positif terhadap pembiayaan UMKM.

4. Koefisien regresi variabel BI Rate sebesar 47083,399, nilai thitung sebesar 1,437 dan signifikansinya 0,161 . Jika dibandingkan dengan nilai $t_{\text {tabel }}$ pada Tabel Nilai $\mathrm{t}$ (one-tailed) dimana signifikansinya 0,05 dan $\mathrm{df}=31$ maka diperoleh nilai $t_{\text {tabel }}$ sebesar 1,70 . Karena koefisien regresi (b) $>0$, nilai $\mathrm{t}_{\text {hitung }}<\mathrm{t}_{\text {tabel }}$ dan signifikansinya sebesar 0,161 maka hipotesis bahwa BI Rate berpengaruh positif terhadap pembiayaan UMKM ditolak.

\footnotetext{
Berdasarkan hasil pengujian hipotesis, penelitian ini menerima hipotesis pertama bahwa ukuran bank berpengaruh positif terhadap pembiayaan UMKM. Hal ini mengindikasikan bahwa peningkatan ataupun penurunan total aset yang menjadi indikator ukuran BPRS
}

selama periode penelitian berpengaruh positif terhadap pembiayaan UMKM yang disalurkan oleh BPRS. Jika terjadi peningkatan total aset BPRS maka pembiayaan UMKM yang disalurkan juga akan mengalami peningkatan. Demikian juga sebaliknya, penurunan total aset akan menyebabkan penurunan pembiayaan UMKM yang disalurkan oleh BPRS. Hasil penelitian ini mendukung penelitian Akbar (2013) dan Ferdinandus (2013) yang membuktikan bahwa ukuran bank berpengaruh positif terhadap penyaluran kredit UMKM.

Berdasarkan hasil pengujian hipotesis, penelitian ini menolak hipotesis ke dua bahwa efisiensi bank berpengaruh negatif terhadap pembiayaan UMKM. Hasil penelitian menunjukkan bahwa efisiensi bank tidak berpengaruh terhadap pembiayaan UMKM yang disalurkan oleh BPRS. Hal ini mengindikasikan bahwa faktor efisiensi bukanlah menjadi penentu bagi BPRS dalam menyalurkan pembiayaan kepada sektor UMKM. Dari data observasi dapat diamati bahwa naik turunnya BOPO sebagai indikator efisiensi tidak dibarengi pula dengan naik turunnya pembiayaan UMKM yang disalurkan oleh BPRS. Hasil penelitian ini tidak sejalan dengan penelitian Nuryakin dan Warjiyo (2006) dalam Satria dan Subegti (2010) yang menemukan bahwa efisiensi bank berpengaruh negatif terhadap penyaluran kredit bank umum di Indonesia.

Hipotesis ke tiga yang menyatakan bahwa likuiditas berpengaruh negatif terhadap pembiayaan UMKM ditolak. Hasil penelitian menunjukkan bahwa likuiditas yang diukur dengan FDR berpengaruh positif terhadap pembiayaan UMKM yang disalurkan oleh BPRS. Hal ini menunjukkan bahwa jika terjadi peningkatan FDR maka akan meningkat pula pembiayaan UMKM, demikian sebaliknya jika FDR turun maka turun pula pembiayaan UMKM yang disalurkan 
oleh BPRS. Padahal secara teori, semakin tinggi FDR pada suatu bank maka akan mengakibatkan semakin rendahnya likuiditas bank. Jika bank dalam kondisi likuiditas rendah atau semakin tidak likuid, bagaimana bank bisa meningkatkan pembiayaan UMKM. Pun demikian sebaliknya, jika semakin rendah FDR pada suatu bank maka akan mengakibatkan semakin tingginya likuiditas bank yang bersangkutan. Bank dengan likuiditas yang tinggi tentu saja bisa meningkatkan pembiayaan UMKM karena ketersediaan dana yang dimiliki oleh bank. Temuan ini tidak sejalan dengan temuan Barus dan Lu (2013) yang dalam penelitiannya berhasil membuktikan bahwa LDR sebagai indikator likuiditas berpengaruh negatif terhadap penyaluran kredit UMKM pada bank umum di Indonesia.

Hipotesis ke empat yang menyatakan bahwa $\mathrm{BI}$ rate berpengaruh positif terhadap pembiayaan UMKM ditolak. Hasil penelitian menunjukkan bahwa BI rate tidak berpengaruh terhadap pembiayaan UMKM yang disalurkan oleh BPRS. Hal ini mengindikasikan bahwa naik turunnya BI rate bukanlah menjadi faktor penentu BPRS dalam memberikan pembiayaan kepada sektor UMKM. Secara teori, meningkatnya $\mathrm{BI}$ rate menyebabkan BPRS meningkatkan pembiayaan UMKM karena BPRS akan memperoleh pendapatan bagi hasil yang lebih besar. Demikian sebaliknya, menurunnya $\mathrm{BI}$ rate menyebabkan turunnya pembiayaan yang diberikan karena BPRS akan memperoleh pendapatan bagi hasil yang lebih kecil. Namun kenyataannya berdasarkan hasil penelitian ini, peningkatan ataupun penurunan BI rate tidak dibarengi dengan peningkatan ataupun penurunan pembiayaan UMKM secara signifikan. Hasil penelitian ini bertentangan dengan penelitian Putra dan Rustariyuni (2015) yang membuktikan bahwa $\mathrm{BI}$ rate mempunyai pengaruh positif terhadap kredit modal kerja yang disalurkan BPR di Provinsi Bali. Hasil penelitian juga tidak sejalan dengan penelitian Pradana (2013) dan Sari (2013) yang juga membuktikan bahwa BI rate berpengaruh positif terhadap kredit yang disalurkan.

\section{SIMPULAN DAN SARAN \\ Simpulan}

1. Ukuran bank berpengaruh positif terhadap pembiayaan UMKM pada BPRS di Indonesia.

2. Efisiensi bank tidak berpengaruh terhadap pembiayaan UMKM pada BPRS di Indonesia.

3. Likuiditas berpengaruh positif terhadap pembiayaan UMKM pada BPRS di Indonesia.

4. BI rate tidak berpengaruh terhadap pembiayaan UMKM pada BPRS di Indonesia.

\section{Saran} memiliki keterbatasan-keterbatasan, diantaranya:

1. Penelitian ini hanya mengamati variabel ukuran bank, efisiensi dan likuiditas bank sebagai faktor internal dan variabel BI rate sebagai faktor eksternal yang mempengaruhi pembiayaan UMKM yang disalurkan oleh BPRS di Indonesia.

2. Periode penelitian hanya tiga tahun sehingga ada kemungkinan hasil penelitian tidak dapat digeneralisasikan untuk kondisi yang berbeda.

maka diajukan beberapa saran berkaitan dengan keterbatasan penelitian maupun saran bagi BPRS, diantaranya sebagai berikut:

1. Bank Pembiayaan Rakyat Syariah diharapkan dapat lebih meningkatkan volume pembiayaan kepada sektor UMKM mengingat bahwa fokus kegiatan BPRS adalah melayani 
segmen UMKM yang tersebar di seluruh wilayah Indonesia dan belum sepenuhnya terjangkau oleh jaringan kantor bank umum syariah dan unit usaha syariah. Dalam hal ini, peranan BPRS adalah menggarap sektor UMKM karena UMKM sudah terbukti menjadi tulang punggung ekonomi bangsa yang tangguh dan berdaya saing.

2. Mengingat kontribusi BPRS terhadap UMKM dalam meningkatkan perekonomian Indonesia maka perlu dibuat kebijakan khusus yang menjadikan BPRS sebagai salah satu institusi perbankan yang nyata dan dapat lebih aktif lagi dalam penyaluran pembiayaan UMKM. Dalam hal ini sudah semestinya pemerintah serius dalam memperhatikan, mendukung dan mendorong keberadaan BPRS di Indonesia sehingga BPRS dapat memperluas jangkauannya kepada masyarakat lebih luas lagi.

3. Mengingat bahwa total aset BPRS sebagai indikator ukuran BPRS berpengaruh positif terhadap pembiayaan UMKM maka untuk menunjang keberadaan BPRS yang kokoh dan kuat di Indonesia, perlu didukung dengan pertumbuhan aset yang signifikan sehingga dapat meningkatkan pelayanan jasa BPRS kepada pelaku UMKM secara optimal yang berdampak pada meningkatnya kepercayaan masyarakat terhadap BPRS melalui jumlah penyaluran pembiayaan yang masif.

4. Untuk penelitian sejenis yang akan datang hendaknya menambahkan variabel-variabel independen lainnya, baik variabel yang sifatnya berasal dari internal BPRS maupun variabel yang sifatnya eksternal atau makroekonomi. Penelitian yang akan datang hendaknya juga menambahkan variabel moderating maupun variabel intervening sehingga diperoleh temuan penelitian yang baru.

5. Periode penelitian hendaknya diperluas lagi agar diperoleh hasil penelitian yang sesuai dengan hipotesis yang diajukan dan hasil penelitian dapat digeneralisasikan.

\section{DAFTAR PUSTAKA}

Akbar, G.R. 2013. Analisis Faktor-Faktor Yang Mempengaruhi Porsi Pembiayaan Usaha Mikro Kecil dan Menengah Yang Disalurkan Oleh Bank Umum Syariah di Indonesia. Departemen Manajemen Fakultas Ekonomi Indonesia.

Barus, A.C. dan M. Lu. 2013. Pengarus Spread Tingkat Suku Bunga dan Rasio Keuangan Terhadap Penyaluran Kredit UMKM Pada Bank Umum di Indonesia. Jurnal Wira Ekonomi Mikroskil 3(1): 1120.

Bank Indonesia Direktorat Perbankan Syariah. Berbagai Data Statistik, Periode 2015, Diakses melalui www.bi.go.id.

Ferdinandus, S. J. 2013. Analisis Penghimpunan dan Penyaluran Kredit Terhadap Usaha Mikro Kecil dan Menengah (Studi Kasus Pada Bank-Bank Yang Terdaftar di Bursa Efek Indonesia Periode 2006-2010). Disertasi. Program Studi Doktor Ilmu Ekonomi, Fakultas Ekonomi dan Bisnis, Universitas Padjadjaran, Bandung.

Harahap, S.S. 2008. Analisis Kritis Atas Laporan Keuangan. Rajagrafindo Persada, Jakarta.

Mulyanto. 2011. Analisis Faktor-Faktor Yang Mempengaruhi Pembiayaan 
Bagi Hasil (Studi Kasus Pada PT. Bank Pembiayaan Rakyat Syariah A). Tesis. Universitas Indonesia, Jakarta.

Pradana, Y. 2013. Analisis Pengaruh LDR, CAR, ROA dan Faktor Eksternal Perbankan Terhadap Volume KPR Pada Bank Persero Periode 2008-2012. Diponegoro Jurnal Of Management 2(3).

Putra, I.G.O.P. dan S.D. Rustariyuni. 2015. Pengaruh DPK, BI Rate dan NPL Terhadap Penyaluran Kredit Modal Kerja Pada BPR di Provinsi
Bali Tahun 2009-2014. E-jurnal Ekonomi Pembangunan Universitas Udayana 4(5): 451-464.

Sari, G. N. 2013. Faktor - Faktor Yang Mempengaruhi Penyaluran Kredit Bank Umum Di Indonesia: Periode 2008.1-2012.2. Jurnal EMBA 1 (3): 931-941.

Satria, D. Dan R.B. Subegti. 2010. Determinasi Penyaluran Kredit Bank Umum di Indonesia Periode 2006-2009. Jurnal Keuangan dan Perbankan 14(3): 415-423. 